\title{
Corrigendum
}

\section{Nutritional evaluation of a bagasse-based ration for cows - CORRIGENDUM}

\section{Geerjanand Saraye}

doi:10.1017/S2040470010000816; published by Cambridge University Press, 8 November 2010

In the abstract by Geerjanand Saraye (2010) presented in Advances in Animal Biosciences, the author's name was listed incorrectly with the author's given name and family name in the wrong sequence. The correct authorship is:

Saraye Geerjanand

The editors would like to apologise to the authors and readers for this mistake.

\section{Reference}

Geerjanand S 2010. Nutritional evaluation of a bagasse-based ration for cows. Advances in Animal Biosciences 1, 459-460. 